\title{
Pengendalian Kualitas Statistik pada Tepung Terigu Menggunakan Peta Kendali Multivariat
} Fitria Dewi Arista ${ }^{1}$, Seza Dwiwulan Ramadini ${ }^{1}$, dan Muhammad Ahsan ${ }^{1 *}$
${ }^{1}$ Departemen Statistika, Fakultas Sains dan Analitika Data, Institut Teknologi Sepuluh Nopember (ITS) *Corresponding author: muh.ahsan@its.ac.id
Received: 17 September 2021 Accepted: 27 September 2021

\begin{abstract}
Persaingan di dunia industri kini semakin ketat, sehingga perlu untuk meningkatkan kualitas pada suatu produk. Pada penelitian ini, karakteristik kualitas yang ingin diuji adalah kadar Moisture, Ash, dan Gluten pada tepung terigu. Metode statistik yang digunakan untuk mengendalikan kualitas proses yaitu diagram kendali multivariat Generalized Variance dan $T^{2}$ Hotelling serta kapabilitas proses dari masing-masing karakteristik kualitas dan kapabilitas proses multivariat. Tujuannya ingin diketahui data pengamatan sudah terkendali atau tidak secara statistik, serta ingin diketahui kapabilitas prosesnya. Dari data yang diperoleh, data dibagi menjadi dua fase dengan fase 1 jumlah subgroup yang diambil sebesar 35 dan fase 2 jumlah subgroup sebanyak 5 dan masing-masing ukuran subgroup adalah 8 . Hasil penelitian ini yaitu data pengamatan bersifat dependen dan data berdistribusi normal multivariat. Diagram kendali Generalized Variance belum terkendali secara statistik, begitu pula dengan peta kendali $T^{2}$ Hotelling belum terkendali secara statistik. Pada analisis kapabilitas proses pada masing-masing karakteristik kualitas, diperoleh bahwa data pengamatan kandungan moisture, ash, dan gluten pada tepung terigu belum kapabel atau belum sesuai dengan spesifikasi yang telah ditentukan.
\end{abstract}

Keywords- Uji Dependensi, Uji Normalitas Multivariat, Generalized Variance, $T^{2}$ Hotelling, kapabilitas proses, moisture, ash, gluten.

\section{PENDAHULUAN}

Era globalisasi yang terus berlanjut membuat berbagai bidang, terutama bidang industri melaju dengan cukup cepat. Dunia bisnis sebagai salah satu bagiannya juga mengalami hal yang sama, perusahaan-perusahaan yang dahulu bersaing hanya pada tingkat berdasar wilayah lokal atau regional kini harus bersaing dengan perusahaan pada tingkat seluruh dunia. Perusahaan yang dapat bertahan dalam jangka waktu yang lama hanya perusahaan yang mampu menghasilkan barang atau jasa dengan kualitas kelas dunia dan dapat menarik daya tarik para konsumen yang dapat bersaing dalam pasar global. Dalam hal ini, kualitas merupakan salah satu hal yang sangat dipertimbangkan bagi konsumen untuk memilih produk yang akan mereka beli. Proses yang baik akan menghasilkan kualitas produk yang baik pula, oleh karena itu sebuah perusahan membutuhkan suatu strategi yang mampu menjaga kestabilan suatu proses dengan tujuan untuk meminimalisasi produk cacat, salah satunya melakukan pengendalian kualitas [1].

Tepung terigu serbaguna terbuat dari gandum jenis soft wheat dengan kandungan protein relatif rendah berkisar antara $8-10 \%$, biasanya digunakan oleh industri-industri yang memproduksi biskuit dan cookies. Mengingat era gobalisasi semakin cepat, semakin banyak persaingan produk dari beberapa perusahaan sejenis. Supaya dapat bertahan dalam persaingan produk, kualitas dari produk yang dihasilkan harus ditingkatkan. Untuk produk tepung terigu, karakteristik kualitas tepung terigu yang diukur dan diuji dari laboratorium adalah moisture, ash, dan gluten. Untuk memonitor kualitas suatu produk dapat digunakan diagram kendali atau peta kendali. Karena karakteristik kualitas yang akan diuji diduga saling berhubungan dengan karakteristik kualitas lainnya, maka metode statistik yang digunakan untuk mengetahui dalam pengendalian proses yaitu diagram kendali multivariat. Terdapat beberapa tipe diagram kendali multivariat, diantaranya adalah tipe Shewhart [2]-[4], Multivariate Exponentially Weighted Moving Average (MEWMA) [5], [6] , dan Multivariate Cumulative Sum (MCUSUM)[7], [8]. Pada penelitian ini, diagram Generalized Variance dan $T^{2}$ Hotelling digunakan untuk memonitor kualtias tepung terigu. Lebih lanjut, kapabilitas proses baik dari masing-masing karakteristik kualitas maupun kapabilitas proses multivariat juga dianalisis.

\section{TINJAUAN PUSTAKA}

\section{A. Peta Kendali Generalized Variance}

Pengendalian proses multivariat membutuhkan perhatian pada dua tingkat, yaitu pada pengendalian proses mean dan pengendalian variabilitas proses. Variabilitas proses dapat dijelaskan dengan matriks kovarian, $\Sigma$. Elemen diagonal utama dari matriks kovarian merupakan variansi masing-masing variabel, sedangkan lemen yang bukan diagonal utama merupakan kovariannya. Terdapat dua pendekatan pada pengendalian variablitas proses, yaitu peta kendali univariat $s^{2}$ dan generalized variance, $|\boldsymbol{S}|$. Peta kendali generalized variance didasarkan pada varian sampel yang tergeneralisasi yang merupakan determinan dari matriks kovarian sampel yang digunakan untuk mengukur dispersi secara multivariat [9].

$$
\begin{gathered}
E(|S|)=b_{1}|\Sigma| \\
V(|S|)=b_{2}|\Sigma|^{2}
\end{gathered}
$$

dimana, 


$$
\begin{gathered}
b_{1}=\frac{1}{(n-1)^{p}} \prod_{i=1}^{p}(n-i) \\
b_{2}=\frac{1}{(n-1)^{2 p}} \prod_{i=1}^{p}(n-i)\left[\prod_{j=1}^{p}(n-j+2)-\prod_{j=1}^{p}(n-j)\right]
\end{gathered}
$$

Sehingga batas kendali pada peta kendali generalized variance dapat dirumuskan sebagai berikut.

$$
\begin{gathered}
U C L=|\Sigma|\left(b_{1}+3 b_{2}^{1 / 2}\right) \\
C L=b_{1}|\Sigma| \\
L C L=|\Sigma|\left(b_{1}-3 b_{2}^{1 / 2}\right)
\end{gathered}
$$

Keterangan:

$\Sigma \quad=$ matriks kovarian pada populasi

$\boldsymbol{S} \quad=$ matriks kovarian pada sampel

$p \quad=$ jumlah variabel karakteristik kualitas

$n \quad=$ jumlah sampel pada tiap subgrup

$U C L \quad=$ batas kendali atas

$L C L \quad=$ batas kendali bawah

Pada praktiknya, $\Sigma$ biasanya akan diestimasikan dengan matriks kovarian $\boldsymbol{S}$, berdasarkan analisis sampelsebelumnya. Jika kasusnya seperti itu, maka $|\Sigma|$ pada UCL, CL, dan LCL dapat diganti dengan $|\boldsymbol{S}| / b 1$.

\section{B. Peta Kendali $T^{2}$ Hotelling}

Peta Kendali yang paling sering digunakan pada pengendalian proses multivariat dan prosedur pengendalian adalah peta kendali $T^{2}$ Hotelling. Peta kendali $T^{2}$ Hotelling digunakan untuk mengendalikan vektor mean pada proses. Terdapat dua versi pada peta kendali $T^{2} H o t e l l i n g$ yaitu untuk data subgrup dan untuk data individual. Pada data subgrup, apabila $\Sigma$ diestimasikan dengan $S$ dan $\overline{\bar{x}}$ digunakan sebagai nilai kontrol pada vektor rata-rata proses maka peta kendali $T^{2}$ Hotelling dapat dirumuskan sebagai berikut [10].

$$
T^{2}=n(\bar{x}-\overline{\bar{x}})^{\prime} S^{-1}(\bar{x}-\overline{\bar{x}})
$$

Fase I digunakan untuk menetapkan pengendalian dimana pengujian proses berada didalam kendali ketika $m$ subgrup awal digambarkan dan statistik sampel $\overline{\bar{x}}$ dan $S$ dihitung. Sedangkan fase II digunakan untuk mengetahui pergeseran mean jika terdapat pengamatan baru. Batas kendali pada fase I dirumuskan sebagai berikut.

$$
\begin{gathered}
U C L=\frac{p(m-1)(n-1)}{m n-m-p+1} F_{\alpha, p, m n-m-p+1} \\
L C L=0
\end{gathered}
$$

Batas kendali pada fase II dirumuskan sebagai berikut.

$$
\begin{gathered}
U C L=\frac{p(m+1)(n-1)}{m n-m-p+1} F_{\alpha, p, m n-m-p+1} \\
L C L=0
\end{gathered}
$$

Keterangan:

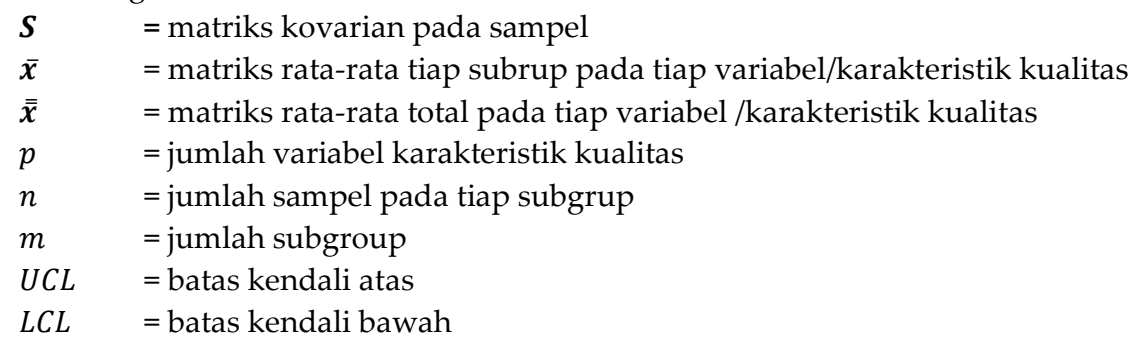

\section{Diagram Ishikawa}

Fishbone atau Ishikawa Diagram diperkenalkan sebagai satu dari tujuh alat kualitas dasar (7 basic quality tools). Fishbone diagram digunakan ketika mengidentifikasi kemungkinan penyebab masalah dan terutama ketika sebuah tim cenderung jatuh berpikir pada rutinitas.

Manfaat fishbone diagram ini dapat membantu untuk menemukan akar penyebab masalah secara user friendly. Suatu tindakan dan langkah improvement akan lebih mudah dilakukan jika masalah dan akar penyebab masalah sudah ditemukan. Fishbone diagram akan mengidentifikasi berbagai sebab potensial dari satu efek atau masalah berdasarkan kategorinya yaitu 5M+E (Material, Manpower, Machine, Method, Measurement, dan Environment) dan menganalisis masalah 
tersebut melalui sesi brainstorming. Setiap kategori mempunyai sebab-sebab yang perlu diuraikan melalui sesi brainstorming.

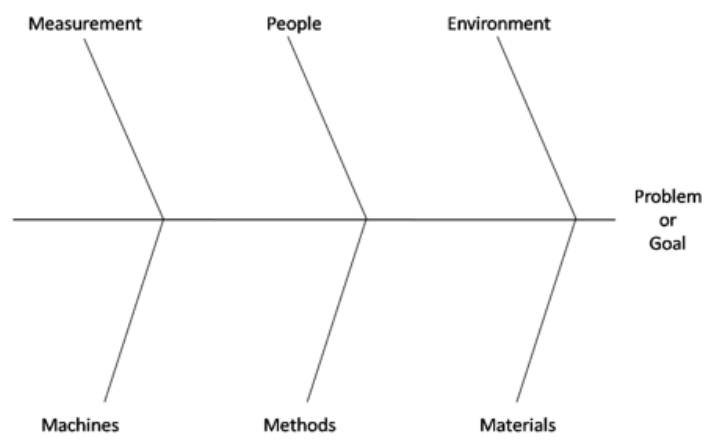

Gambar 1. Diagram Ishikawa

\section{Analisis Kapabilitas Multivariat}

Kapabilitas proses merupakan suatu pengukuran yang digunakan untuk mengevaluasi keseluruhan proses. Jika asumsi peta kendali dalam keadaan terkendali dan data berdistribusi multivariat normal telah terpenuhi, maka nilai indeks kapabilitas proses $\left(C_{p}\right)$ multivariat dapat dihitung menggunakan metode weighting average [11]. Berikut adalah persamaan untuk menghitung MPCIs (indeks kapabilitas multivariat).

$$
\begin{aligned}
& M C_{p}=\sum_{k=1}^{p} W_{k} C_{p}\left(x_{k}\right) \\
& M C_{p k}=\sum_{k=1}^{p} W_{k} C_{p k}\left(x_{k}\right)
\end{aligned}
$$

Dimana $M C p, M C p k$ berturut-turut merupakan bentuk $C p, C p k$ dalam keadaan multivariat dengan $W k$ merupakan pembobot berdasarkan kepentingan dengan $\sum_{k=1}^{p} W_{k}=1$. Dengan rumus indeks kapabilitas secara univariat adalah sebagai berikut.

$$
\begin{gathered}
C_{p}=\frac{U S L-L S L}{6 \sigma} \\
C_{p k}=\min \left\{\left(\frac{U S L-\bar{x}}{3 \sigma}\right),\left(\frac{\bar{x}-L S L}{3 \sigma}\right)\right\}
\end{gathered}
$$

dimana indeks $C_{p}$ digunakan untuk menyatakan tingkat presisi, presisi yaitu ukuran kedekaran antara satu pengamatan dengan pengamatan lainnya yang ukurannya dapat ditunjukkan oleh variabilitas $(\sigma)$, sedangkan indeks $C_{p k}$ digunakan untuk menyatakan tingkat akurasi dan presisi, akurasi yaitu ukuran kedekatan hasil pengamatan dengan nilai target.

Kriteria penilaian indeks $C_{p}$ dan $C_{p k}$ yaitu sebagai berikut.

1. Jika nilai indeks $C_{p}$ dan $C p k<1$ maka proses tidak kapabel.

2. Jika nilai indeks $1<\mathrm{C}_{\mathrm{p}}$ dan $\mathrm{C}_{\mathrm{pk}}<1,33$ maka proses hampir sesuai dengan spesifikasi.

3. Jika nilai indeks $C_{p}$ dan $C_{p k}>1,33$ maka proses kapabel.

Saat proses belum terkendali secara statistik maka indeks yang digunakan adalah $P_{p}$ dan $P_{p k}$. Rumus indeks $P_{\mathrm{p}}$ dan $P_{\mathrm{pk}}$ adalah sebagai berikut.

$$
\begin{gathered}
P_{p}=\frac{U S L-L S L}{6 \sigma} \\
P_{p k}=\min \left\{\left(\frac{U S L-\mu}{3 \sigma}\right),\left(\frac{\mu-L S L}{3 \sigma}\right)\right\}
\end{gathered}
$$

Sehingga persamaan untuk menghitung MPCIs (indeks kapabilitas multivariat) saat proses belum terkendali adalah sebagai berikut.

$$
\begin{aligned}
M P_{p} & =\sum_{k=1}^{p} W_{k} P_{p}\left(x_{k}\right) \\
M P_{p k} & =\sum_{k=1}^{p} W_{k} P_{p k}\left(x_{k}\right) .
\end{aligned}
$$

\section{METODOLOG|}

\section{A. Sumber Data}

Data yang digunakan merupakan data sekunder berupa hasil uji laboratorium produk tepung. Data yang digunakan yaitu 35 subgroup dari fase I dan 5 subgroup dari fase II.

\section{B. Variable Penelitian}

Variabel penelitian yang digunakan adalah Moisture, Ash, dan Gluten dengan menggunakan diagram kendali 
Multivariate yaitu Generalized Variance dan $\mathrm{T}^{2}$ Hotelling. Batas spesifikasi yang digunakan berbeda-beda tergantung dari variabel penelitian. Batas spesifikasi untuk variabel Moisture adalah 13\% sampai 14\%. Batas spesifikasi untuk variabel Ash adalah $0 \%$ sampai $0,6 \%$. Dan batas spesifikasi untuk variabel Gluten adalah 22\% sampai $26 \%$. Adapun struktur data fase I dan fase II yang digunakan pada penelitian ini untuk diagram kendali Generalized Variance dan $\mathrm{T}^{2}$ Hotelling sebagai berikut.

Tabel 1. Struktur Data Fase I

\begin{tabular}{ccccc}
\hline \multirow{2}{*}{ Subgroup } & \multirow{2}{*}{$\begin{array}{c}\text { Ukuran } \\
\text { Subgroup }\end{array}$} & \multicolumn{3}{c}{ Karakteristik Kualitas } \\
\cline { 3 - 5 } & 1 & $\mathrm{X}_{111}$ & $\mathrm{X}_{2}$ & $\mathrm{X}_{3}$ \\
\hline \multirow{3}{*}{1} & 2 & $\mathrm{X}_{112}$ & $\mathrm{X}_{212}$ & $\mathrm{X}_{311}$ \\
& $\ldots$ & $\ldots$ & $\ldots$ & $\ldots$ \\
& 8 & $\mathrm{X}_{118}$ & $\mathrm{X}_{218}$ & $\mathrm{X}_{318}$ \\
& $\ldots$ & $\ldots$ & $\ldots$ & $\ldots$ \\
& 1 & $\mathrm{X}_{111}$ & $\mathrm{X}_{211}$ & $\mathrm{X}_{311}$ \\
& 2 & $\mathrm{X}_{112}$ & $\mathrm{X}_{212}$ & $\mathrm{X}_{312}$ \\
& $\ldots$ & $\ldots$ & $\ldots$ & $\ldots$ \\
& 8 & $\mathrm{X}_{118}$ & $\mathrm{X}_{218}$ & $\mathrm{X}_{318}$ \\
\hline \hline
\end{tabular}

Tabel 2. Struktur Data Fase II

\begin{tabular}{ccccc}
\hline \multirow{2}{*}{ Subgroup } & \multirow{2}{*}{$\begin{array}{c}\text { Ukuran } \\
\text { Subgroup }\end{array}$} & \multicolumn{3}{c}{ Karakteristik Kualitas } \\
\cline { 2 - 5 } & 1 & $\mathrm{X}_{1}$ & $\mathrm{X}_{2}$ & $\mathrm{X}_{3}$ \\
\hline \multirow{3}{*}{1} & 2 & $\mathrm{X}_{112}$ & $\mathrm{X}_{211}$ & $\mathrm{X}_{311}$ \\
& $\ldots$ & $\ldots$ & $\ldots$ & $\mathrm{X}_{312}$ \\
& 8 & $\mathrm{X}_{118}$ & $\mathrm{X}_{218}$ & $\ldots$ \\
& $\ldots$ & $\ldots$ & $\ldots$ & $\ldots$ \\
& 1 & $\mathrm{X}_{111}$ & $\mathrm{X}_{211}$ & $\mathrm{X}_{311}$ \\
& 2 & $\mathrm{X}_{112}$ & $\mathrm{X}_{212}$ & $\mathrm{X}_{312}$ \\
5 & $\ldots$ & $\ldots$ & $\ldots$ & $\ldots$ \\
& 8 & $\mathrm{X}_{118}$ & $\mathrm{X}_{218}$ & $\mathrm{X}_{318}$ \\
\hline \hline
\end{tabular}

\section{Langkah Penelitian}

Langkah penelitian yang dilakukan adalah sebagai berikut.

1. Mengidentifikasi masalah.

2. Mengumpulkan data.

3. Melakukan eksplorasi data.

4. Melakukan uji dependensi.

5. Melakukan uji asumsi normalitas multivariat.

6. Melakukan analisis data dengan diagram kendali Generalized Variance dan $T^{2}$ Hotelling pada fase I dan fase II.

7. Melakukan analisis dekomposisi untuk fase I menggunakan alfa 0,05.

8. Membuat diagram Ishikawa untuk penyebab out of control dari diagram kendali.

9. Melakukan uji kapabilitas proses untuk masing-masing variabel penelitian.

10. Melakukan uji kapabilitas proses multivariat.

11. Menarik kesimpulan.

\section{ANALISIS DAN PEMBAHASAN}

\section{A. Statistika Deskriptif Data}

Data yang digunakan pada penelitian ini yaitu karakteristik biskuit dimana terdapat tiga variabel, yaitu moisture, ash, dan gluten. Berikut merupakan output statistika deskriptif dari karakteristik kualitas pada tepung terigu.

\begin{tabular}{ccccc}
\multicolumn{5}{c}{ Tabel 3. Statistika Deskriptif Karakter Kualitas Tepung Terig } \\
\hline \hline Variabel & Mean & StDev & Median & Range \\
\hline Moisture & 13,471 & 0,290 & 13,475 & 1,650 \\
Ash & 0,54616 & 0,03063 & 0,55000 & 0,16000 \\
Gluten & 23,722 & 2,200 & 23,770 & 11,360 \\
\hline \hline
\end{tabular}


Tabel 3 menunjukkan ukuran pemusatan data berupa rata-rata data pada variabel moisture sebesar 13,471 dengan median 13,475. Hal tersebut menunjukkan bahwa distribusi dari data tersebut memiliki sedikit skewness kiri karena nilai mean sedikit lebih kecil dari nilai median dan masing-masing 50\% data berada di atas dan di bawah nilai median. Nilai standar deviasi sebesar 0,290 dan nilai range sebesar 1,650 menunjukkan bahwa persebaran dari data pada variabel moisture tidak terlalu besar. Nilai mean pada data variabel ash yang bernilai sedikit lebih kecil daripada nilai median, mengindikasikan distribusi memiliki sedikit skewness kiri. Dengan nilai standar deviasi sebesar 0,03063 dan range sebesar 0,16 menunjukkan bahwa persebaran data kecil. Sedangkan persebaran data pada variabel gluten cukup besar, dengan nilai standar deviasi dan range berturut-turut adalah 2,2 dan 11,360. Bentuk distribusi dari variabel gluten juga tidak sepenuhnya normal, namun memiliki sedikit skewness kiri seperti variabel lainnya, karena nilai mean lebih kecil dari nilai median. Namun demikian, semua rata-rata pada ketiga variabel karakteristik kualitas tepung terigu masih dalam batas spesifikasi yang ditetapkan perusahaan.

\section{B. Uji Dependensi}

Salah satu asumsi yang harus dipenuhi dalam membuat diagram kendali Generalized Variance dan $T^{2}$ Hotelling adalah ketiga karakteristik kualitas yang memiliki hubungan satu sama lain untuk menghasilkan perhitungan kovarians. Oleh sebab itu, diperlukan uji dependensi untuk membuktikan apakah data hasil uji laboratorium tepung terigu bersifat dependen atau tidak. Didapatkan hasil uji dependensi dari data hasil uji laboratorium tepung terigu sebagai berikut.

Tabel 4. Uji Dependensi pada Data Hasil Uji Laboratorium Tepung Terigu

\begin{tabular}{cc}
\hline \hline Data & p-value \\
\hline $\begin{array}{c}\text { Kualitas Tepung } \\
\text { Terigu }\end{array}$ & 0,008 \\
\hline \hline
\end{tabular}

Tabel 4 menunjukkan hasil uji dependensi, didapatkan $p$-value sebesar 0,008 atau $p$-value kurang dari $\alpha(\alpha=0,05)$, maka keputusannya adalah tolak $\mathrm{H}_{0}$. Sehingga data hasil uji laboratorium tepung terigu untuk diagram kendali Generalized Variance dan $T^{2}$ Hotelling, antar variabel moisture, ash, dan gluten memiliki korelasi secara multivariat.

\section{Uji Normalitas Multivariat}

Asumsi lain yang harus dipenuhi dalam pembuatan diagram kendali Generalized Variance dan $T^{2}$ Hotelling adalah pengujian normalitas multivariat. Didapatkan uji normalitas multivariat dari data karakteristik kualitas pada tepung terigu untuk diagram kendali Generalized Variance dan $T^{2}$ Hotelling sebagai berikut.

Tabel 5. Uji Normalitas Multivariat pada Data Hasil Uji Laboratorium Tepung Terigu

\begin{tabular}{cc}
\hline \hline Data & p-value \\
\hline $\begin{array}{c}\text { Kualitas Tepung } \\
\text { Terigu }\end{array}$ & 0,001625 \\
\hline
\end{tabular}

Tabel 5 menunjukkan hasil pengujian analisis normalitas multivariat, didapatkan nilai p-value sebesar 0,001625 atau $p$-value kurang dari $\alpha(\alpha=0,05)$, maka keputusannya adalah tolak $\mathrm{H}_{0}$, sehingga data karakteristik kualitas pada tepung terigu untuk diagram kendali Generalized Variance dan $T^{2}$ Hotelling tidak berdistribusi normal multivariat. Namun, untuk keperluan analisis lanjutan, data hasil uji laboratorium tepung terigu untuk diagram kendali Generalized Variance dan $T^{2}$ Hotelling diasumsikan berdistribusi normal multivariat.

\section{Peta Kendali Generalized Variance Fase I}

Analisis peta kendali Generalized Variance dilakukan sebelum pembuatan peta kendali $T^{2}$ Hotelling yang bertujuan untuk mengetahui apakah variabilitas dari 35 data dari tiga karakteristik kualitas proses produski tepung terigu pada fase I telah terkendali secara statistik atau tidak. Peta kendali Generalized Variance pada fase I disajikan dalam Gambar 2.

Gambar 2 merupakan peta kendali Generalized Variance menggunakan data fase I dengan subgroup sebesar 35 dan ukuran sampel setiap subgroup sebesar 8. Dari gambar, tampak bahwa terdapat data yang di luar batas kendali. Jadi, dapat disimpulkan bahwa variabilitas data karakteristik kualitas pada tepung terigu belum terkendali secara statistik. Diasumsikan assignable cause diketahui, maka dapat dilakukan penanganan berupa eliminasi pada data yang out of control. Eliminasi dilakukan pada subgroup ke-34 karena jarak antara nilai determinan dari $S_{34}$ lebih jauh terhadap UCL dibandingkan nilai determinan dari S29 terhadap UCL. Berikut diagram kendali Generalized Variance setelah revisi pertama. 


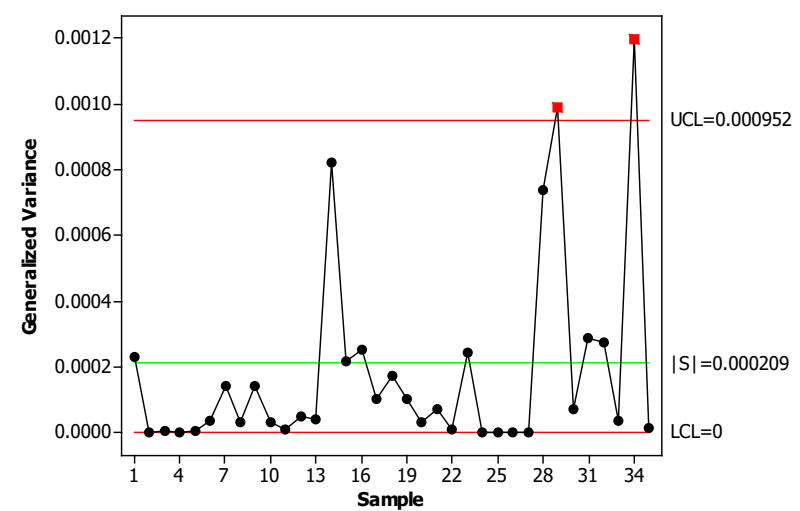

Gambar 2. Diagram Kendali Generalized Variance Data Karakteristik Kualitas Tepung Terigu pada Fase 1.

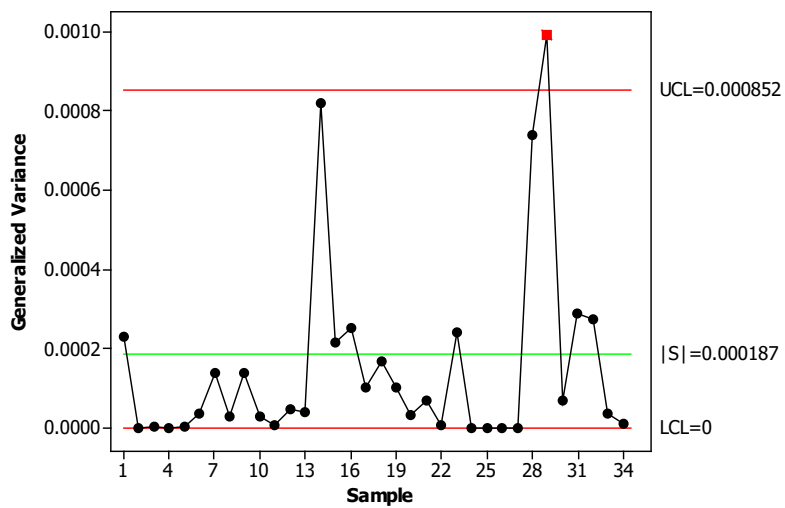

Gambar 3. Revisi 1 Diagram Kendali Generalized Variance Karakteristik Kualitas Tepung Terigu

Dapat dilihat dari gambar 3 bahwa setelah dilakukan eliminasi pertama dengan penghapusan data subgroup ke34 pada peta kendali Generalized Variance, dapat disimpulkan bahwa data karakteristik kualitas pada tepung terigu belum terkendali secara statistik karena masih terdapat data out of control, dimana pada data subgroup ke-29 berada diluar batas kendali atas. Jika diasumsikan assignable cause diketahui, maka dapat dilakukan penanganan berupa mengeliminasi pada data out of control, yaitu pada subgroup ke-29 karena jarak antara nilai determinan dari $S_{34}$ berada diluar UCL. Berikut merupakan peta kendali Generalized Variance setelah revisi kedua.

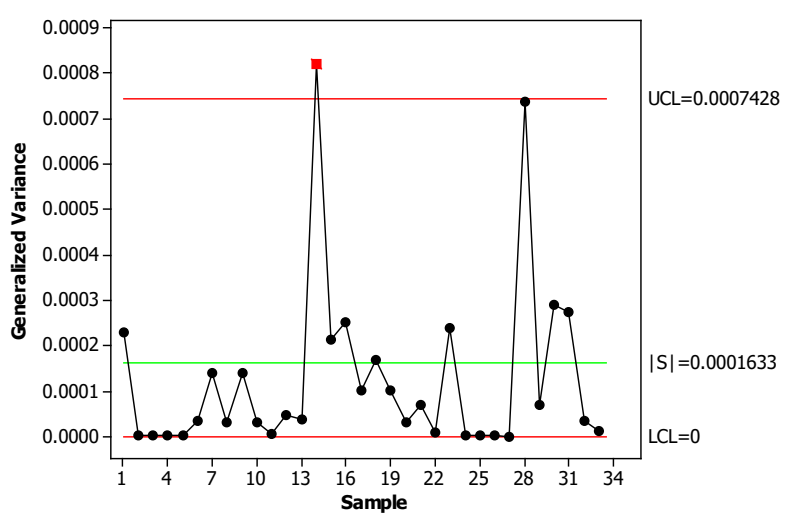

Gambar 4. Revisi 2 Diagram Kendali Generalized Variance Data Karakteristik Kualitas Tepung Terigu pada Fase 1

Berdasarkan Gambar 4, setelah dilakukan eliminasi data kedua dengan penghapusan data subgroup ke-29 dapat disimpulkan bahwa variabilitas data karakteristik kualitas pada tepung terigu belum terkendali secara statistik (out of control) dimana pada data subgroup ke-14 berada diluar batas kendali. Namun, karena eliminasi sudah dilakukan sebanyak dua kali, maka pengeliminasi data dihentikan dan dilanjutkan pada analisis selanjutnya. 


\section{E. Peta Kendali $T^{2}$ Hotelling Fase I}

Setelah dilakukan analisis terhadap peta kendali Generalized Variance pada fase I, selanjutnya akan dilakukan analisis peta kendali $T^{2}$ Hotelling untuk mengendalikan rata-rata proses produksi tepung terigu secara statistik. Data yang digunakan adalah 35 subgrup dengan tiga karakteristik kualitas. Gambar 5 merupakan peta kendali $T^{2}$ Hotelling pada fase I.

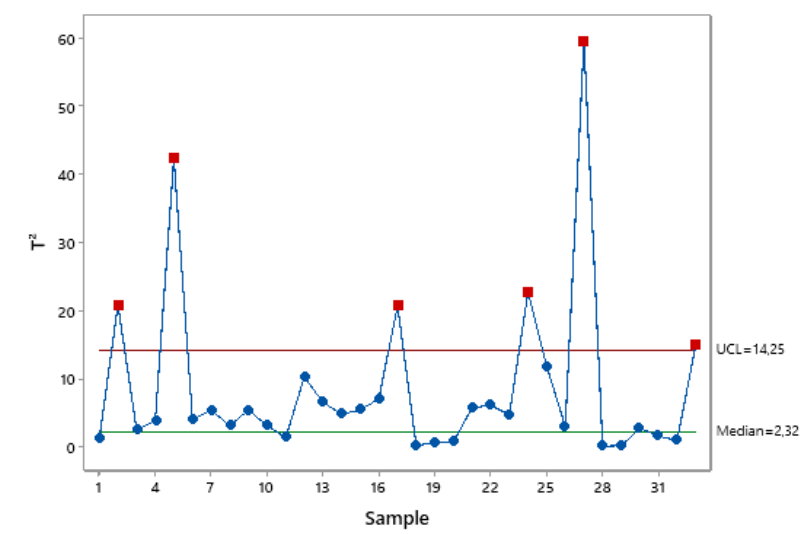

Gambar 5. Peta Kendali $T^{2}$ Hotelling Fase I Data Karakteristik Kualitas Tepung Terigu

Dapat dilihat pada Gambar 5 bahwa pada peta kendali $T^{2}$ Hotelling fase I terdapat titik-titik pengamatan yang berada di luar batas kendali yang ditandai dengan warna merah. Artinya, rata-rata proses dari karakteristik kualitas tepung terigu belum terkendali secara statistik. Data pengamatan yang berada di luar batas kendali terjauh adalah data pengamatan pada subgroup ke-27. Diasumsikan bahwa data pengamatan pada sugbroup ke-27 disebabkan oleh assignable cause, sehingga dapat dilakukan penanganan dengan menghapus data subgrup ke-27 dari pengamatan dan dibuat peta kendali $T^{2}$ Hotelling kembali. Hasil perbaikan ditunjukkan pada Gambar 6.

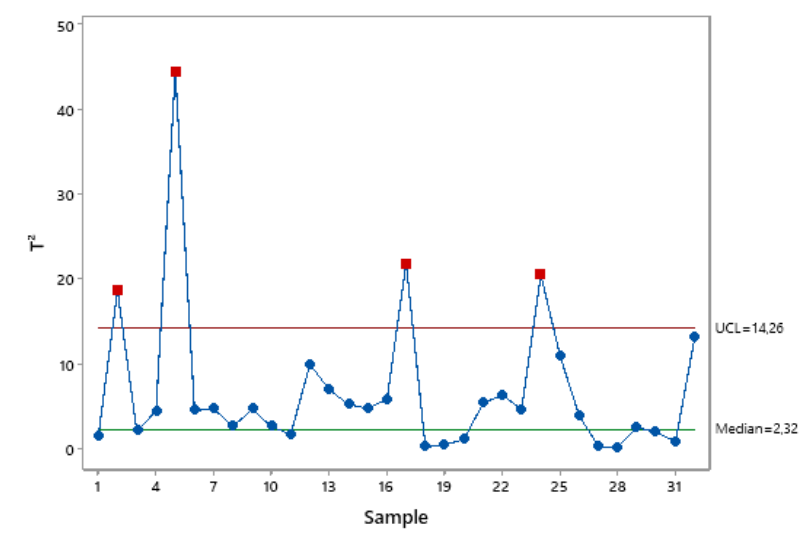

Gambar 6. Revisi 1 Peta Kendali $T^{2}$ Hotelling Fase I Data Karakteristik Kualitas Tepung Terigu

Gambar 6 menunjukkan bahwa masih terdapat data yang out of control. Hal tersebut berarti bahwa rata-rata proses dari ash, moisture, dan gluten pada tepung terigu belum terkendali secara statistik. Data pengamatan yang berada di luar batas kendali paling jauh adalah subgroup ke-5. Oleh karena itu, perlu dilakukan pengidentifikasian penyebab out of control dan diasumsikan penyebabnya adalah penyebab khusus (assignable cause), sehingga dilakukan penanganan dengan menghapus data out of control terjauh dari batas kendali yaitu subgroup ke-5. Hasil revisi tersebut ditunjukkan pada Gambar 7.

Gambar 7 menunjukkan bahwa masih terdapat titik yang berada di luar batas kendali atas (UCL). Maka, dapat disimpulkan bahwa rata-rata proses dari karakteristik kualitas tepung terigu tidak terkendali secara statistik dengan menggunakan peta kendali $T^{2}$ Hotelling, namun untuk keperluan analisis, maka dilanjutkan pada tahap analisis selanjutnya. 


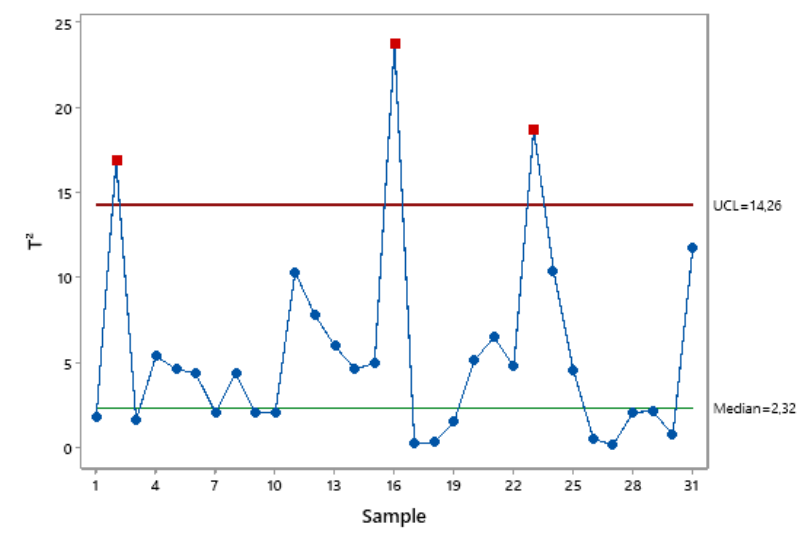

Gambar 7. Revisi 2 Peta Kendali $T^{2}$ Hotelling Fase I Data Karakteristik Kualitas Tepung Terigu

\section{F. Peta Kendali Generalized Variance Fase II}

Peta kendali yang dianalisis pada fase II menggunakan 5 subgrup data baru untuk memonitoring pergeseran mean proses pada produksi tepung terigu dengan acuan yang digunakan adalah matriks variance-covariance yang diperoleh dari fase I yang telah diperbaiki sebanyak dua kali. Peta kendali Generalized Variance sendiri bertujuan untuk mengendalikan variabilitas dari 5 subgrup pengamatan baru secara statistik.

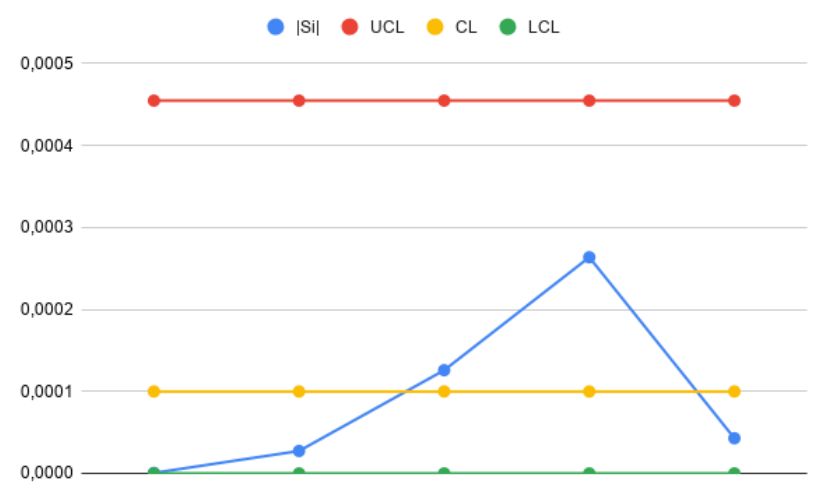

Gambar 8. Diagram Kendali Generalized Variance Data Karakteristik Kualitas Tepung Terigu pada Fase II.

Gambar 4 memberikan informasi bahwa peta kendali Generalized Variance menggunakan data fase II dengan subgroup sebesar 5 dan ukuran sampel setiap subgroup sebesar 8 dapat disimpulkan bahwa variabilitas data karakteristik kualitas pada tepung terigu telah terkendali secara statistik, karena tidak ada data yang berada di luar batas kendali. Dengan nilai CL sebesar 0,000099959 dari perhitungan perkalian antara determinan S dengan B1, nilai batas kendali atas (UCL) sebesar 0,00045478 dan nilai batas kendali bawah (LCL) sebesar 0.

\section{G. Peta Kendali $T^{2}$ Hotelling Fase II}

Pembuatan peta kendali $T^{2}$ Hotelling pada fase II ini bertujuan untuk melihat apakah terdapat pergeseran mean proses dari data yang telah terkendali secara statistik terhadap 5 subgrup data baru. Peta kendali $T^{2}$ Hotelling ini mengacu pada mean proses masing-masing karakteristik kualitas dan matriks variance-covariance yang diperoleh dari fase I yang telah direvisi sebanyak dua kali.Hasil peta kendali $T^{2}$ Hotelling ditampilkan pada Gambar 9.

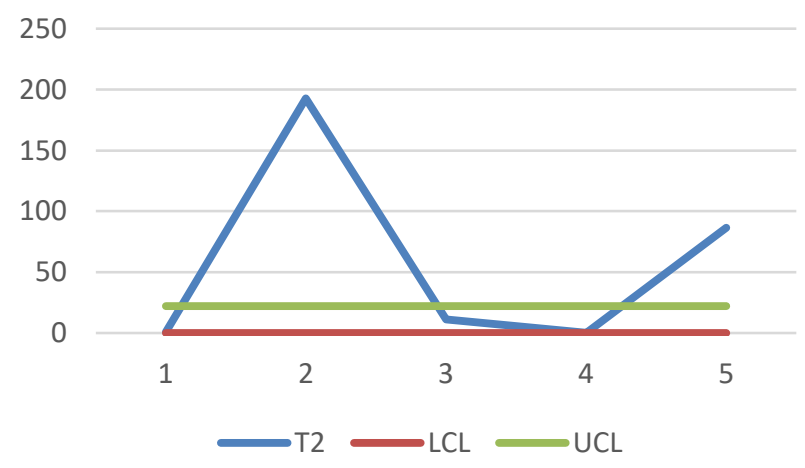

Gambar 9. Peta Kendali $T^{2}$ Hotelling Fase II Data Karakteristik Kualitas Tepung Terigu 
Gambar 9 menunjukkan bahwa 5 subgrup data fase II tidak terkendali secara statistik dan tidak terjadi pergeseran mean proses. Hal ini ditandai dengan subgroup data pada fase II, data ke-2 dan data ke-5 yang out of control. Maka, dapat disimpulkan bahwa pada fase tidak terjadi pergeseran mean pada proses produksi tepung terigu terhadap data baru.

\section{H. Analisis Dekomposisi}

Tabel 6 menunjukkan bahwa dapat dilihat pada semua sampel out of control variabel ketebalan memiliki nilai di lebih besar dari nilai $\chi 2$ sebesar 3,8415 yang berarti, dapat disimpulkan penyebab out of control terdapat pada variabel moisture.

\begin{tabular}{cccc}
\multicolumn{4}{c}{ Tabel 6. Nilai Dekomposisi } \\
\hline \hline Sampel & $\mathbf{d}_{\mathbf{1}}$ & $\mathbf{d}_{\mathbf{2}}$ & $\mathbf{d}_{\mathbf{3}}$ \\
\hline Sampel ke-2 & 10,1277 & 5,96150 & 0,942857 \\
Sampel ke-16 & 16,9803 & 2,37368 & 5,46167 \\
Sampel ke-23 & 17,1325 & 1,41071 & 0,0008158 \\
\hline \hline
\end{tabular}

\section{Diagram Ishikawa}

Diagram Ishikawa (diagram tulang ikan/cause-and-effect matrix) adalah diagram yang menunjukkan penyebabpenyebab dari sebuah even yang spesifik. Diagram Ishikawa dapat membantu mengidentifikasi faktor-faktor yang signifikan memberi efek terhadap sebuah proses. Dari data karakteristik kualitas tepung terigu, diketahui bahwa karakteristik kualitas yang menyebabkan data out of control adalah variabel moisture. Berikut adalah diagram Ishikawa dari akar permasalahan variabel moisture yang menyebabkan data out of control.

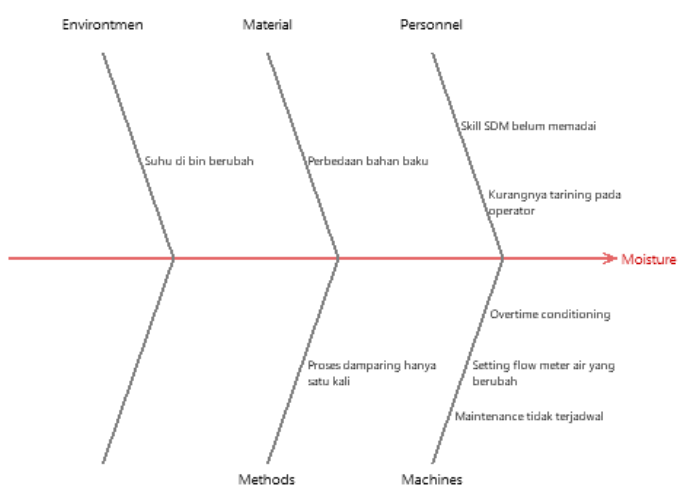

Gambar 10. Diagram Ishikawa pada Variabel Moisture

Gambar 10 merupakan diagram Ishikawa dari penyebab out of control variabel moisture. Terdapat beberapa faktor diantaranya yaitu faktor mesin dengan penyebabnya adalah settingan flowmeter air yang sering berubah-ubah dan jadwal maintenance yang tidak terjadwal. Selain faktor mesin, terdapat pula faktor manusia dengan penyebab skill SDM yang belum memadai dan kurangnya training pada operator. Pada faktor material terdapat bahan baku yang berbeda negara dari supplier, sehingga memengaruhi kandungan bahan baku karena kondisi lingkungan. Kemudian faktor metode dengan penyebab proses dampening yang seharusnya dilakukan 2 kali namun hanya dilakukan satu kali, dengan kendala meminimalisir cost. Pada faktor lingkungan, moisture tidak sesuai spesifikasi apabila suhu di bin panas, hal ini terjadi karena kondisi lingkungan di luar yang dapat mempengaruhi kondisi suhu di bin.

\section{J. Analisis Kapabilitas Proses}

Analisis kapabilitas proses adalah teknik yang memiliki aplikasi di banyak segmen siklus produk, termasuk desain produk dan proses, manajemen rantai pasokan, perencanaan produksi atau manufaktur, dan manufaktur. Berikut merupakan kapabilitas proses dari data hasil uji laboratorium tepung terigu dengan variabel penelitian Moisture.

Gambar 9 dapat memberikan informasi bahwa nilai $P p$ sebesar 0,65 yakni lebih kecil dari 1,33. Hal ini menunjukkan bahwa rata-rata proses pada kandungan Moisture tepung terigu dengan batas spesifikasi yang ditentukan yaitu antara $13 \%$ hingga $14 \%$ belum kapabel atau tidak sesuai dengan batas spesifikasi sehingga perlu dilakukan perbaikan proses untuk meningkatkan kualitas karakteristik hasil produksi. Selanjutnya, berikut merupakan kapabilitas proses dari data hasil uji laboratorium tepung terigu dengan variabel penelitian Ash. 


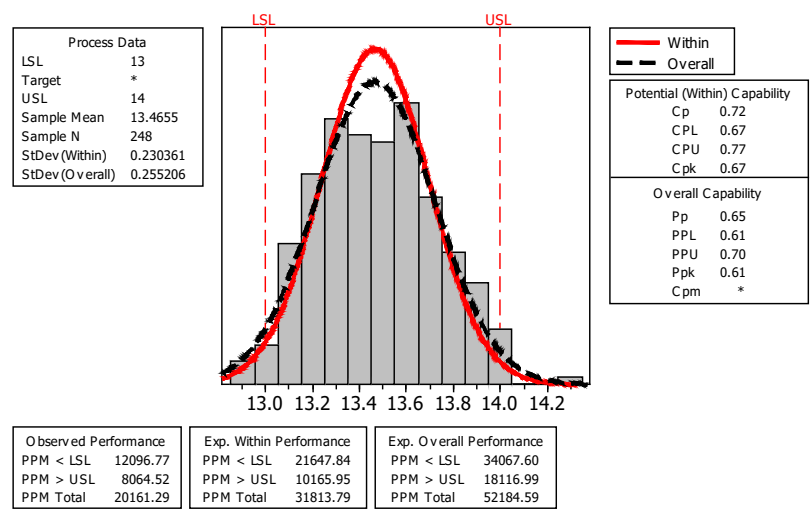

Gambar 9. Kapabilitas Proses untuk Data Hasil Uji Laboratorium Tepung Terigu dengan Variabel Moisture.

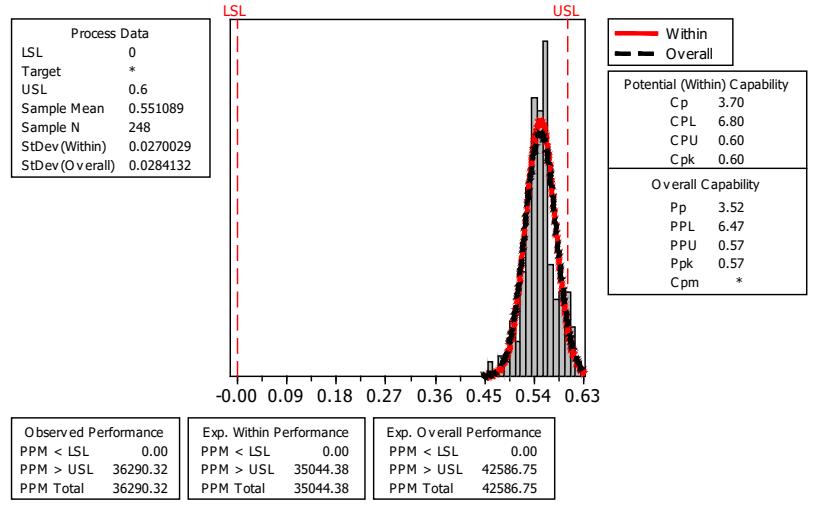

Gambar 10. Kapabilitas Proses untuk Data Hasil Uji Laboratorium Tepung Terigu dengan Variabel Ash.

Dari gambar 10 dapat memberikan informasi bahwa nilai $P p$ sebesar 3,52 yakni lebih besar dari 1,33. Hal ini menunjukkan bahwa rata-rata proses pada kandungan Ash tepung terigu dengan batas spesifikasi yang ditentukan yaitu antara $0 \%$ hingga $0,6 \%$ belum kapabel atau tidak sesuai dengan batas spesifikasi yang ditentukan karena masih terdapat out of control pada diagram kendali Generalized Variance dan $T^{2}$ Hotelling. Selanjutnya, berikut merupakan kapabilitas proses dari data hasil uji laboratorium tepung terigu dengan variabel penelitian Gluten.

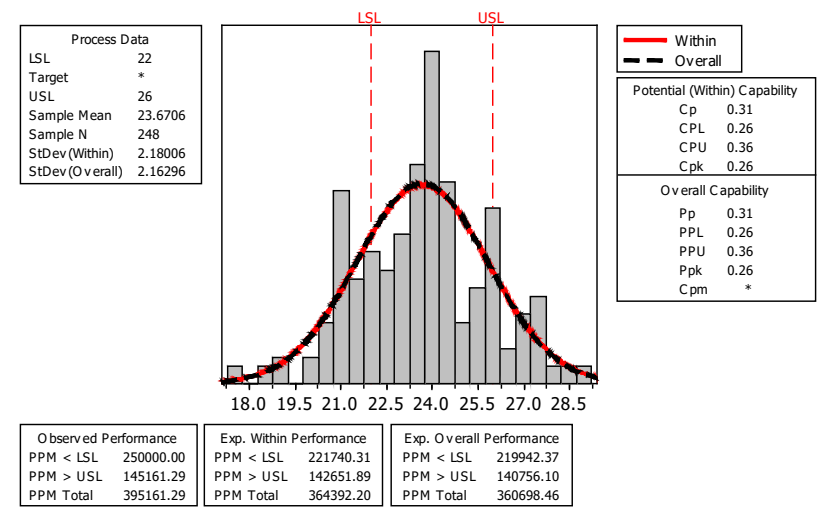

Gambar 11. Kapabilitas Proses untuk Data Hasil Uji Laboratorium Tepung Terigu dengan Variabel Gluten.

Berdasarkan gambar 11 menunjukkan bahwa nilai $P p$ sebesar 0,31 yaitu lebih kecil dari 1,33. Hal ini menunjukkan bahwa rata-rata proses pada kandungan Gluten tepung terigu dengan batas spesifikasi yang ditentukan yaitu antara $22 \%$ hingga $26 \%$ belum kapabel atau tidak sesuai dengan batas spesifikasi sehingga perlu dilakukan perbaikan proses untuk meningkatkan kualitas karakteristik hasil produksi.

Tabel 7. Nilai $M P p$ dan $M P p k$

\begin{tabular}{lll}
\hline \hline Karakteristik Kualitas & $M P_{p}$ & $M P_{p k}$ \\
\hline Moisture, Ash, Gluten & 1,4933 & 0,4800 \\
\hline \hline
\end{tabular}

Kapabilitas proses merupakan suatu pengukuran yang digunakan untuk mengevaluasi keseluruhan proses. Nilai indeks $P p$ dan P pk multivariat dilakukan perhitungan dengan pembobot sebesar 0,33. Setelah diperoleh indeks kapabilitas untuk masing-masing karakteristik kualitas, kemudian dilakukan perhitungan untuk indeks kapabilitas multivariat. Nilai $M P p>1,33$ yang menunjukkan nilai presisi yang tinggi, namun proses produksi tepung terigu tidak kapabel dalam presisi karena pada diagram kendali Generalized Variance dan $T^{2}$ Hotelling masih terdapat data yang out of 
control. Sedangkan, nilai $M P p k<1,33$, menandakan bahwa proses produksi tepung terigu tidak kapabel dalam presisi dan akurasi. Maka, dapat disimpulkan bahwa proses produksi tepung terigu tidak memenuhi spesifikasi yang telah ditetapkan atau dapat dikatakan proses tidak kapabel.

\section{KESIMPULAN}

Kesimpulan yang didapatkan dari penelitian ini adalah data karakteristik kualitas berupa variabel moisture, ash, dan gluten tidak berdistribusi normal multivariat karena $p$-value $<0,05$. Uji asumsi dependensi yang menghasilkan $p$-value $<$ 0,05 menunjukkan bahwa antar variabel moisture, ash, dan gluten memiliki korelasi secaramultivariat.Statistika deskriptif menunjukkan bahwa data dari ketiga variabel karakteristik kualitas memiliki mean yang lebih kecil dari median,sehingga distribusi data tersebut memiliki sedikit skewness kiri. Persebaran data dari ketiga variabel tersebut juga cukup kecil karena nilai standar deviasi dan jangkauan yang relatif kecil, kecuali pada variabel gluten yang memiliki persebaran data cukup besar. Namun, rata-rata dari ketiga variabel masih dalam batas spesifikasi. Pengendalian variabilitas proses secara statistik pada fase I menggunakan peta kendali Generalized Variance menunjukkan bahwa masih terdapat data out of control walaupun sudah dilakukan perbaikan sebanyak dua kali, sehingga variabilitas proses dari karakteristik kualitas tepung terigu belum terkendali secara statistik. Pada analisis rata-rata proses menggunakan peta kendali $T^{2} H_{o t e l l i n g}$ pada fase I didapatkan bahwa masih ada data yang out of control setelah dilakukan perbaikan sebanyak dua kali, sehingga dapat disimpulkan bahwa rata-rata proses dari data karakteristik kualitas tepung terigu belum terkendali secara statistik Selanjutnya, analisis pengendalian variabilitas secara statistik menggunakan peta kendali Generalized Variance I pada fase II menunjukkan bahwa tidak ada data yang di luar batas kendali, yang artinya variabilitas proses dari data baru karakteristik kualitas tepung terigu telah terkendali secara statistik. Pada analisis rata-rata proses menggunakan peta kendali $T^{2}$ Hotelling pada fase II didapatkan bahwa terdapat data yang out of control, sehingga dapat disimpulkan bahwa ada pergeseran mean proses dari data baru karakteristik kualitas tepung terigu. Analisis kapabilitas proses variabel moisture menunjukkan bahwa proses tidak kapabel karena nilai $P_{p}$ kurang dari 1,33 dan nilai $P_{p k}$ kurang dari 1,33. Pada analisis kapabilitas proses variabel $a s h$, didapatkan nilai $P_{p}$ lebih dari 1,33, namun nilai $P_{p k}$ kurang dari 1,33, sehingga dapat disimpulkan bahwa proses tidak kapabel. Analisis kapabilitas proses variabel gluten, didapatkan nilai $P_{p}$ dan $P_{p k}$ kurang dari 1,33, sehingga dapat disimpulkan bahwa proses tidak kapabel. Nilai indeks kapabilitas multivariat $M P_{p}$ bernilai lebih dari 1,33, namun nilai $M P_{p k}$ kurang dari 1,33, sehingga proses tidak kapabel.

\section{REFERENSI}

[1] V. Gaspersz and F. Avanti, "Lean Six Sigma for Manufacturing and Service Industries (Bogor." Vinchristo Publisher Publication, 2011.

[2] M. Ahsan, M. Mashuri, H. Kuswanto, D. D. Prastyo, and H. Khusna, “Outlier detection using PCA mix based T2 control chart for continuous and categorical data," Commun. Stat. - Simul. Comput., pp. 1-28, Apr. 2019, doi: 10.1080/03610918.2019.1586921.

[3] M. Mashuri, H. Haryono, D. F. Aksioma, W. Wibawati, M. Ahsan, and H. Khusna, “Tr (R2) control charts based on kernel density estimation for monitoring multivariate variability process," Cogent Eng., vol. 6, no. 1, p. 1665949, 2019.

[4] M. Ahsan, M. Mashuri, H. Kuswanto, D. D. Prastyo, and H. Khusna, "T2 Control Chart based on Successive Difference Covariance Matrix for Intrusion Detection System," in Journal of Physics: Conference Series, 2018, vol. 1028, no. 1, p. 12220.

[5] H. Khusna, M. Mashuri, Suhartono, D. D. Prastyo, and M. Ahsan, "Multioutput Least Square SVR Based Multivariate EWMA Control Chart," J. Phys. Conf. Ser., vol. 1028, no. 1, p. 12221, 2018, [Online]. Available: http://stacks.iop.org/1742$6596 / 1028 / \mathrm{i}=1 / \mathrm{a}=012221$.

[6] H. Khusna, M. Mashuri, S. Suhartono, D. D. Prastyo, and M. Ahsan, "Multioutput least square SVR based multivariate EWMA control chart: The performance evaluation and application," Cogent Eng., Oct. 2018, doi: 10.1080/23311916.2018.1531456.

[7] H. Khusna, M. Mashuri, M. Ahsan, S. Suhartono, and D. D. Prastyo, "Bootstrap-based maximum multivariate CUSUM control chart," Qual. Technol. Quant. Manag., vol. 17, no. 1, pp. 52-74, 2020.

[8] H. Khusna, M. Mashuri, Suhartono, D. D. Prastyo, M. H. Lee, and M. Ahsan, "Residual-based maximum MCUSUM control chart for joint monitoring the mean and variability of multivariate autocorrelated processes," Prod. Manuf. Res., vol. 7, no. 1, pp. 364-394, 2019.

[9] J. A. Villasenor Alva and E. G. Estrada, "A generalization of Shapiro-Wilk's test for multivariate normality," Commun. Stat. Methods, vol. 38, no. 11, pp. 1870-1883, 2009.

[10] D. Montgomery, Introduction to statistical quality control. New York, 2009.

[11] D. C. Montgomery, Introduction to Statistical Quality Control, Sixth Edition. Arizona State University: John Wiley and Sons, 2009. 